\title{
Descapitalització educativa i segona onada de despoblació
}

Miguel González-Leonardo, Antonio López-Gay i Joaquín Recaño, Centre d'Estudis Demogràfics i Departament de Geografia, Universitat Autònoma de Barcelona

Els desequilibris territorials entre comunitats autònomes espanyoles es tradueixen en l'emigració de titulats universitaris d'algunes regions i en la concentració del capital humà qualificat en altres. L'interior peninsular i la cornisa cantàbrica, on la intensitat de les sortides s'aguditza amb el canvi de segle, es veuen afectats per dinàmiques de descapitalització educativa i per l'emigració de joves urbans. La despoblació ja no és un fenomen exclusiu del medi rural, sinó que s'estén a les ciutats de les comunitats autònomes secularment expulsores. Castella i Lleó és la regió més afectada, amb pèrdues migratòries anuals per mobilitat de llarga distància -interregional i exterior- del -13,4\%o entre els joves de les capitals de província, -9,25\%o en altres municipis urbans i -9,63\%o en el medi rural. Al panorama migratori deficitari, cal afegir l'elevat nivell de qualificació dels emigrants, ja que més del 53,8\% dels joves que marxen tenen estudis universitaris, i només el 36,7\% dels que arriben des d'altres parts d'Espanya. Madrid es consolida com el principal receptor de talent, que és destinació del 38,7\% dels moviments migratoris interregionals dels joves nacionals. A més, els fluxos d'entrada presenten un elevat nivell formatiu, amb un $64,8 \%$ de titulats universitaris. En aquest Perspectives Demogràfiques analitzem els moviments migratoris de la població de 25 a 39 anys nascuts a Espanya que travessen algun límit autonòmic en el període 2013-2017: els fluxos entre regions, el nivell educatiu d'aquests intercanvis i el balanç migratori segons l'àmbit territorial (urbà i rural). Per desenvolupar aquesta recerca utilitzem l'Estadística de Variacions Residencials (EVR) i l'Enquesta de Població Activa (EPA).

\section{MADRID: PRINCIPAL RECEPTOR DE LA MIGRACIÓ INTERNA D’ESPANYOLS}

La major part dels fluxos migratoris de llarga distància es dirigeixen des de llocs perifèrics cap a altres que actuen com a centres del sistema territorial, on es localitzen les ciutats globals (Sassen, 1991). Segons les dades de l'EVR, entre 2013 i 2017 hi va haver 776.345 moviments migratoris de llarga distància protagonitzats per població nascuda a Espanya de 25 i 39 anys, un flux mitjà anual de 155.269 migracions, el 80,7\% dins dels límits nacionals i un 19,3\% amb origen o destinació cap a l'estranger. La Figura 1 mostra, a través d'un gràfic circular, la direcció i dimensió dels fluxos migratoris entre comunitats autònomes. Un 38,7\% dels moviments interregionals, 48.505, arriben o surten de la Comunitat de Madrid, amb 29.320 entrades a l'any, 19.185 sortides i un flux net positiu de 10.135 joves, el més elevat de tot el conjunt nacional. El 35\% dels immigrants, prop de deu mil, provenen de Castella-la Manxa i Castella i Lleó. Una part de les pèrdues de la primera es veu compensada per la desconcentració de Madrid cap al sector septentrional de la regió manxega. No en el cas de Castella i Lleó, on les entrades
FIGURA 1. Fluxos migratoris interregionals de la població nascuda a Espanya entre 25 i 39 anys: flux mitjà anual del període 2013-2017

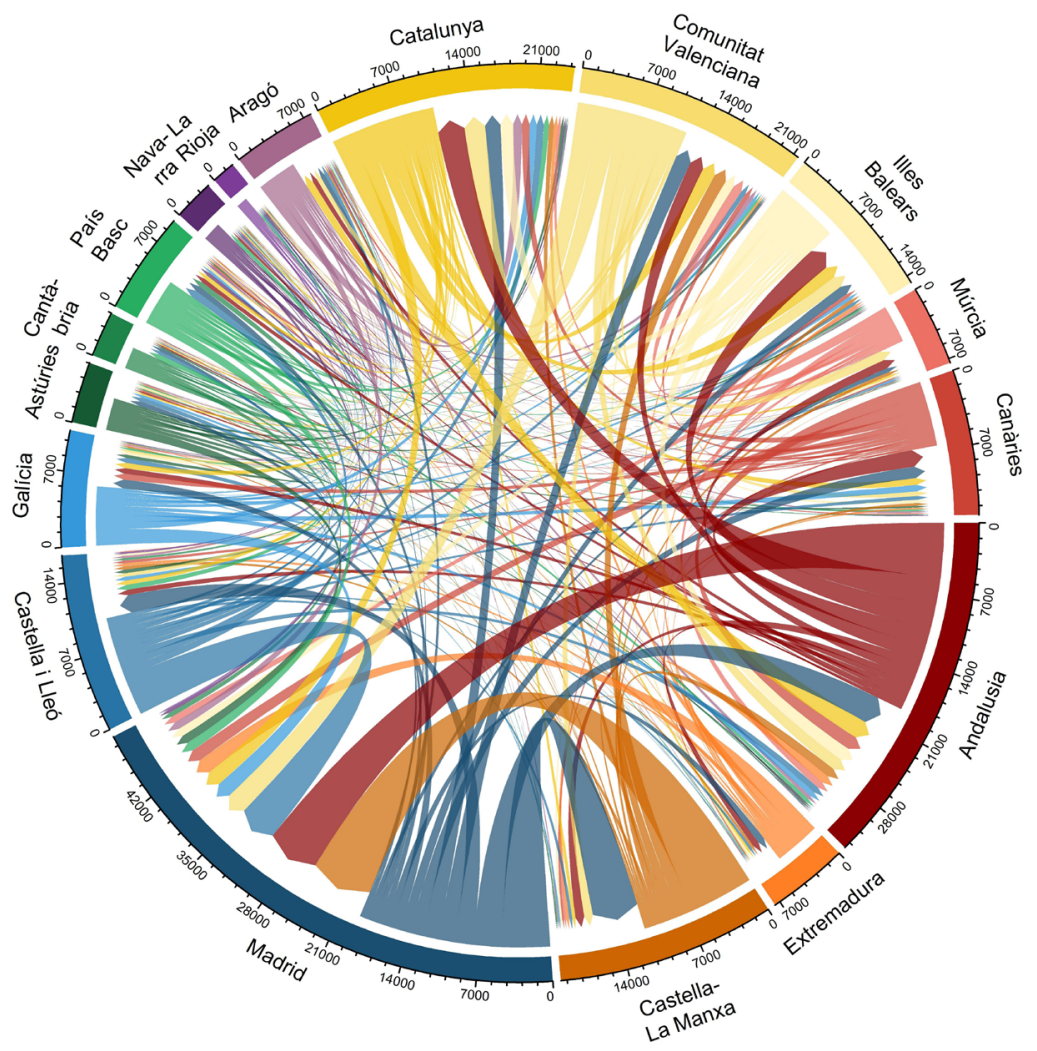

Font: Elaboració pròpia a partir de l'Estadística de Variacions Residencials (INE). 
des de la capital d'Espanya són escasses. Extremadura, Galícia, Astúries, Cantàbria, Andalusia, la Comunitat Valenciana, Canàries i Catalunya també tenen contingents emigratoris destacats cap a Madrid, però a les tres darreres no representen pèrdues relatives significatives.

Catalunya, lluny del poder d'atracció de Madrid, és el segon centre receptor, amb 10.443 emigrants l'any, 13.654 immigrants i un saldo positiu de 3.211 joves. Els seus fluxos d'entrada provenen majoritàriament d'Andalusia, la Comunitat Valenciana i, en menor mesura, de les Illes Balears, Madrid i Aragó. Catalunya registra saldo positiu en la relació migratòria amb Andalusia i la Comunitat Valenciana, però el balanç entre emigrants i immigrants queda equilibrat amb les altres tres comunitats autònomes. Les Illes Balears també tenen un saldo net significatiu i es nodreixen principalment de població procedent de les regions mediterrànies, amb una marcada rotació migratòria derivada de l'estacionalitat turística. La resta de fluxos interregionals són poc rellevants en termes quantitatius i les sortides queden més o menys compensades amb les entrades que arriben des d'altres parts d'Espanya.

\section{FUGA DE CERVELLS I ACUMULACIÓ DEL CAPITAL HUMÀ QUALIFICAT}

El "brain drain", o la fuga de cervells, consisteix en la pèrdua de capital humà qualificat en un territori (Docquier i Rapoport, 2012). L'emigració del talent local té conseqüències negatives per al desenvolupament endogen i alimenta els processos d'acumulació en les àrees receptores, que es beneficien del capital humà importat (González-Leonardo i López-Gay, 2019). La mobilitat s'explica com una acció racional de l'individu per obtenir més rèdits per les seves habilitats, que es veuen millor recompensades en llocs de primer nivell en la jerarquia territorial (Sánchez-Moral et al., 2018). Com més gran és el desajust entre les habilitats i els retorns pagats per aquestes en les regions d'origen, el "brain drain" té una incidència més significativa. Els factors no econòmics, com l'oferta d'activitats culturals o la diversitat, també han de ser tinguts en compte en l'elecció del lloc de residència (Florida, 2002), encara que les variables econòmiques -ocupació, salari, xarxes personalstenen un pes més destacat en la decisió de moure's (Martin-Brelot et al., 2010). En general, els migrants solen estar positivament seleccionats respecte a la població d'origen (Bernard i Bell, 2018). No obstant això, la selectivitat també pot ser negativa en alguns contextos, sobretot quan els factors d'expulsió tenen major rellevància.

Segons les dades de l'EPA per al període 2013-2017 (Figura 2), existeix selectivitat emigratòria positiva als moviments interregionals dels joves espanyols, mesurada a partir del percentatge de població amb estudis universitaris a totes les comunitats autònomes, excepte Catalunya i Madrid. És a dir, els autòctons de 25 a 39 anys que han emigrat tenen un nivell educatiu superior respecte als seus homòlegs que romanen a la regió de naixement. Castilla i Lleó, Galícia, Astúries, Navarra, Castella-la Manxa, Cantabria i la Comunitat Valenciana són les comunitats amb una selectivitat emigratòria més marcada: entre el $45 \mathrm{i}$ el $55 \%$ dels joves que marxen tenen estudis universitaris, en front al 30-35\% dels sedentaris. A Madrid, no obstant, el 42,9\% dels

FIGURA 2. Percentatge de població nascuda a Espanya entre 25 i 39 anys amb titulació universitària per CCAA i estatus migratori, $2013-2017$

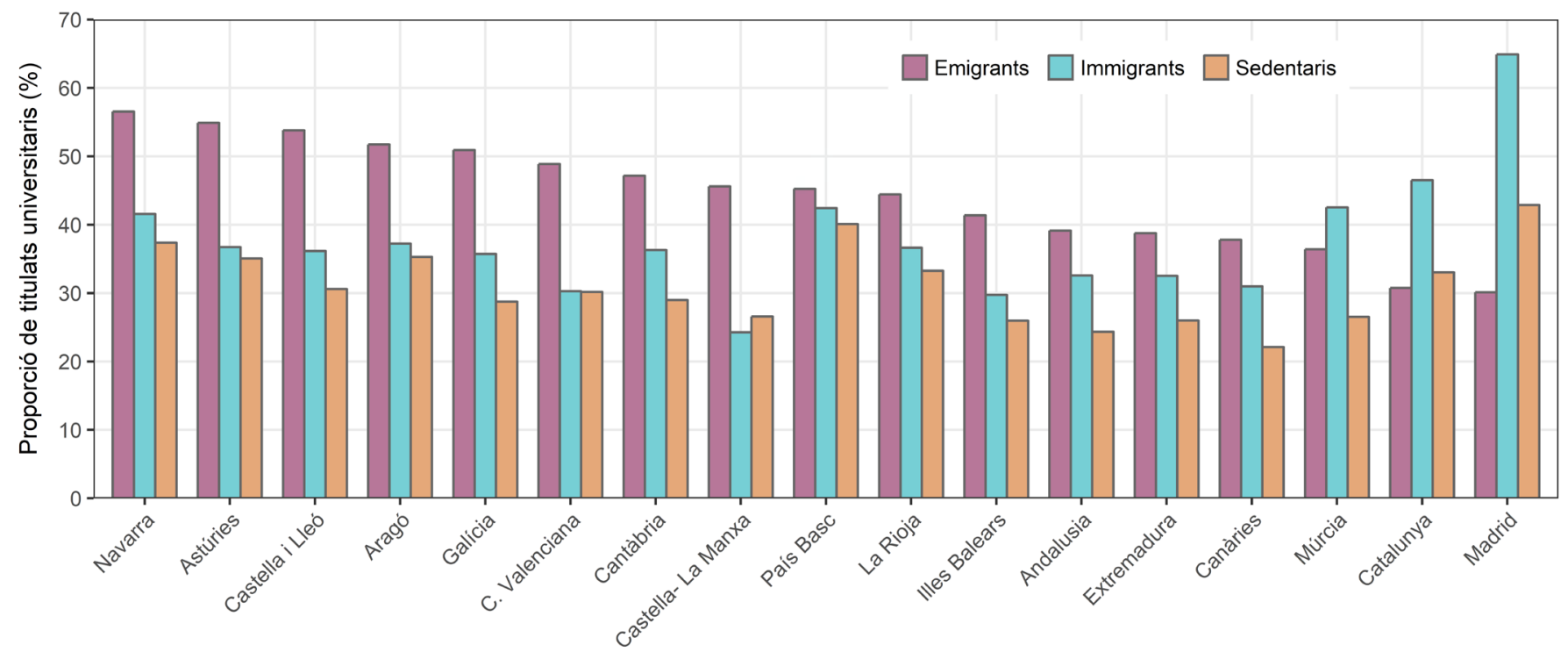

Font: Elaboració pròpia a partir de l'Enquesta de Població Activa (INE). 
autòctons residents eren titulats universitaris i un 30,1\% en el cas dels emigrats. Per tant, existeix un marcat caràcter de selectivitat negativa als fluxos de sortida i una tendència cap a la selecció sociodemogràfica de la població resident a Madrid.

Si es compara el perfil educatiu de la població que emigra amb el de les persones que arriben des d'altres comunitats autònomes, es distingeix que els primers estan molt més qualificats que els segons a les mateixes regions on la selectivitat emigratòria és més marcada. Per tant, no només marxen els més qualificats, sinó que els joves procedents d'altres regions tenen un nivell educatiu més baix respecte als que marxen. A Castella i Lleó, només el 36,7\% dels nadius d'altres comunitats autònomes que resideixen a la regió tenen titulació universitària, davant del 53,8\% dels locals que han emigrat cap a altres parts de la geografia espanyola. A Castella-la Manxa, els percentatges són del 45,6 i 24,3\%, en aquest ordre. Tan sols a Madrid i Catalunya, regions a les que se suma Múrcia, els immigrants tenen un nivell educatiu més alt que els emigrants. A la Comunitat de Madrid, el 64,9\% dels joves procedents d'altres regions tenen estudis universitaris i el 30,1\% del col-lectiu emigrat. Per tant, Madrid es posiciona com el principal importador de talent nascut a altres parts d'Espanya i com a centre del sistema migratori de capital humà qualificat, a la vegada que expulsa joves sense estudis universitaris cap a llocs més barats per viure. Una part important d'aquests darrers es traslladen a les províncies de Guadalajara i Toledo, continuen treballant a Madrid i realitzen moviments pendulars diaris.

\section{LES CAPITALS DE PROVÍNCIA DE LES REGIONS EMISSORES ES DESPOBLEN}

La despoblació és el resultat de processos demogràfics que venen de lluny. Des de la segona meitat del segle XIX, l'emigració de població rural cap a les ciutats cobra major intensitat i s'aguditza entre finals de la dècada de 1950 i mitjans dels anys 70, quan es produeix l'èxode rural massiu (Recaño, 2017). En endavant, la intensitat emigratòria es redueix; continua, però, havent-hi un degoteig constant de població rural. Al mateix temps, el protagonisme de les migracions rural-urbà disminueix, doncs la capacitat del camp per nodrir de població jove a les ciutats és més limitada. Com a conseqüència, creix el protagonisme dels fluxos migratoris interurbans en direcció a les àrees metropolitanes de primer nivell a la jerarquia territorial (Sánchez-Moral et al., 2018; González-Leonardo y López-Gay, 2019).

Segons les dades de l'EVR per al quinquenni estudiat (Figura 3), les capitals de província de les regions emissores són els municipis que més joves entre 25 i 39 anys perden com a conseqüència de les migracions de llarga distància, per damunt d'altres àmbits urbans $i$ del medi rural. Novament, Castella i Lleó és la comunitat autònoma més perjudicada, amb una taxa neta anual negativa de $-13,4 \%$ o les capitals de província, -9,25\% al conglomerat dels municipis urbans restants i -9,63\%o al medi rural. El mateix succeeix a Castella-la Manxa i Astúries. De la mateixa forma que a Cantàbria, Andalusia i Galícia, tot i que en aquests casos les taxes netes negatives no són tan intenses. Les capitals provincials d'aquestes comunitats autònomes no només perden població nascuda al mateix municipi, sinó que

FIGURA 3. Taxa neta de migració anual per a la població nascuda a Espanya entre 25 i 39 anys, per CCAA i àmbit territorial: $2013-2017$

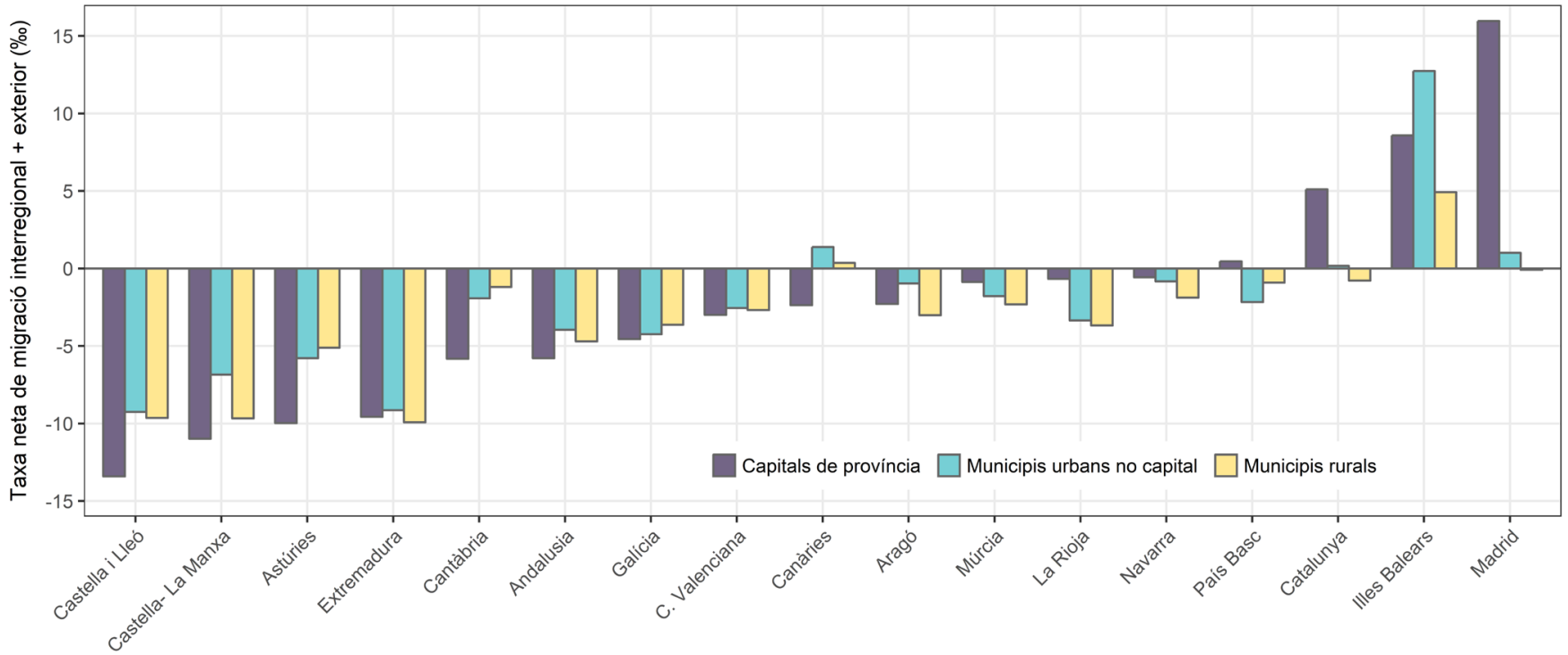

Font: Elaboració pròpia a partir de l'Estadística de Variacions Residencials i del Padró Municipal d'Habitants (INE).

Nota: Es consideren municipis urbans tots aquells majors de 10.00o habitants i els de menor mida inclosos a l’Atles Estadístic de les Àrees Urbanes del Ministeri de Foment. 
també són utilitzades com a trampolí pels joves de ciutats més petites i del medi rural, nascuts a la mateixa regió. Aquests es desplacen inicialment a les capitals provincials de la seva comunitat per estudiar o incorporar-se al mercat laboral, i posteriorment emigren cap a àmbits urbans de més entitat. A l'altra cara de la moneda es troba el municipi de Madrid, amb un creixement migratori mitjà anual del 16\%. L'augment poblacional a la resta de municipis urbans de la Comunitat de Madrid és contingut i el balanç del medi rural proper a zero. Les Illes Balears presenten taxes netes positives destacades a les tres tipologies territorials, sobretot a les urbs no capitals. La distribució espacial de l'activitat turística a l'arxipèlag balear té molt a veure en aquesta qüestió. Les capitals catalanes també creixen per l'arribada de joves espanyols, principalment a expenses dels fluxos d'entrada cap a Barcelona.

\section{EMIGRACIÓ, DESCAPITALITZACIÓ EDUCA- TIVA I DESPOBLACIÓ URBANA: UN TERRI- TORI CADA VEGADA MÉS POLARITZAT}

Les comunitats autònomes secularment expulsores no només tenen balanços migratoris negatius de població jove, sinó que els fluxos de sortida es caracteritzen per un èxode de titulats universitaris bastant intens, mentre que les entrades tenen un nivell educatiu més baix. Els municipis urbans d'aquestes regions, principalment les capitals de província, tenen series dificultats per retenir als joves locals al territori, sobretot als més preparats. Aquests emigren cap a llocs de primer nivell a la jerarquia territorial, davant la manca d'oportunitats laborals d'acord al seu nivell formatiu. Les regions de l'interior i les del nord d'Espanya són les més afectades, principalment Castella i Lleó, on el balanç migratori negatiu de les seves capitals i la sortida

Referències bibliogràfiques

Bernard, A.; Bell, M. (2018). "Educational selectivity of internal migrants". Demographic Research, 39 (29): 835-854.

Docquier, F.; Rapoport, H. (2012). “Globalization, Brain Drain, and Development". Journal of Economic Literature, 50 (3): 681-730.

Florida, R. (2002). "The Economic Geography of Talent". Annals of the Association of American Geographers, 92 (4): $743-755$

González-Leonardo, M.; López-Gay, A. (2019). "El nuevo paradigma de las migraciones internas en España: migrantes urbanos más móviles y cualificados. El caso de Castilla y León". Scripta Nova. Revista Electrónica de Geografía y Ciencias Sociales, 23 (609): 1-37.

Martin-Brelot, H.; Grossetti, M.; Eckert, D.; Gritsai, O; Kovácz, Z. (2010). "The Spatial Mobility of the Creative Class: A European Perspective". International Journal of Urban and Regional Research, 34 (4): 854-870.

de titulats universitaris són especialment cridaners. Aquestes ciutats, petites i intermèdies del teixit urbà espanyol, presenten una escassa competitivitat a l'economia globalitzada actual. Han quedat al marge de grans inversions de capital, tant nacional com internacional, i no han estat capaces de crear una economia basada en noves tecnologies aprofitant el capital humà endogen. En molts casos, es tracta de ciutats que no s'han recuperat dels processos de desindustrialització o que encara tracten de mantenir un teixit productiu amb certa obsolescència i un important dèficit d'activitats d'alt valor afegit.

Madrid es consolida com la principal aglomeració del talent procedent d'altres parts d'Espanya, amb forts processos d'acumulació del capital humà qualificat i dinàmiques d'expulsió que afecten a les persones dels estrats socioeducatius més baixos. Els fluxos d'aquests es canalitzen majoritàriament cap a les províncies de Guadalajara i Toledo. Barcelona també es posiciona com a guanyador net de capital humà qualificat procedent de la resta d'Espanya, encara que molt allunyada del poder centrípet de la capital espanyola. Les Illes Balears registren un balanç migratori positiu; el perfil educatiu de les entrades és, però, més baix, doncs el sector turístic balear demanda un contingent important de mà d'obra de baixa qualificació. Els resultats posen de relleu una marcada i creixent polarització del territori espanyol, amb forts processos de descapitalització educativa a les regions emissores, on la despoblació ja no és un procés exclusiu del medi rural, sinó que s'expandeix als àmbits urbans. Al mateix temps, es produeixen dinàmiques d'acumulació, principalment a Madrid, que evidencien la tendència inherent dels processos de globalització a concentrar capital, activitats d'alt valor afegit i població molt educada en unes poques ciutats globals.

Correspondència dirigida a:

Miguel González-Leonardo mgonzalez@ced.uab.es

Crèdits

Gràfics: Anna Turu Maquetació: Xavier Ruiz Vilchez

Agraïments

Als editors per convidar-nos a escriure aquesta publicació i pels comentaris aportats durant el procés d'elaboració. A Pau Miret i Teresa Menacho pel seu recolzament en qüestions metodològiques referents a l'EPA i a Anna Turu per l'elaboració dels gràfics.

Aquest treball ha estat finançat a través d'una beca FI, dintre del projecte "Integrating Research Infrastructure for European expertise on Inclusive Growth from data to policy -InGRID2-" (730998). També ha estat recolzat pel projecte "Comportamientos demográficos y estrategias residenciales: apuntes para el desarrollo de nuevas políticas sociales" (CSO2016-79142-R).
Enllaç url

http://ced.uab.es/difusion/butlletiperspectives-demografiques

Contacte

Centre d'Estudis Demogràfics. Carrer de Ca n'Altayó, Edifici E2 Universitat Autònoma de Barcelona 08193 Bellaterra / Barcelona Espanya

Telèfon: +34 935813060 Correu: demog@ced.uab.es Web: http://ced.uab.es/ 